\title{
Obtaining Salt (NACL) Tolerant Olive Plants: I) Some Physiological and Anatomical Characteristics of Olive Plants Growing in Harsh Saline Zones
}

M. Cantos, J. Troncoso, J. Liñán

and $\mathrm{A}$. Troncoso.

Instituto de Recursos Naturales y

Agrobiología de Sevilla (CSIC).

Av. Reina Mercedes 10 ,

P.O. Box 1052, 41080 Sevilla, Spain.
H. Rapaport

Instituto de Agricultura Sostenible

(CSIC).

Alameda del Obispo s/n

P.O. Box 4084, 14080 Córdoba, Spain

Keywords: Olea europaea, L, leaf nutrient levels, leaf tissue.

\section{Abstract}

With the final aim of obtaining salt tolerant olive plants, olive cvs. growing in the olive Germplasm Bank (World Collection) of Córdoba (Spain) (WC-CO) and plants growing in three harsh saline zones, each divided into two subzones, were selected. The zones and subzones were: "Odiel" River Marsh (Huelva) with the subzones "Raboconejo" (O-RC) y "Acebuchal" (O-AC); "Doñana" National Park (Huelva) with the subzones "Zainao" (D-ZA) and "Velázquez" (D-VE) and "Bahia de Cádiz" Natural Park with the subzones "S. Fernando" (C-SF) and "Puerto Real" (C-PR).

There were differences between the leaf mineral composition of the cvs. growing in $\mathrm{WC}-\mathrm{CO}$, and plants growing in the different saline zones, that showed higher contents of $\mathrm{Na}$ and $\mathrm{Cl}$ (influence of $\mathrm{NaCl}$ in soil and air) and generally lower levels of $\mathrm{N}, \mathrm{K}$, and $\mathrm{Ca}$. Among oligoelements, saline zone plants presented higher $\mathrm{Fe}$ and lower $\mathrm{Mn}$ and $\mathrm{Cu}$ contents.

Anatomical observations revealed high variability in the leaves of the plants from the high saline zones, which in many cases were thinner than the WC-CO cv.s, largely due to reduced spongy mesophyll. A slight relationship was seen between leaf $\mathrm{Na}$ and $\mathrm{Cl}$ content and total leaf and palisade parenchyma thickness for the leaves from saline zones.

\section{INTRODUCTION}

Soil salinity is a serious problem in some arid areas of the Mediterranean basin, where plants are subjected to high temperature regimes and water deficits. In these areas, the use of saline waters sometimes represents the only possibility for irrigation. However salt stress conditions affect growth, production, leaf drop, etc. of cultivated trees. Noncultivated or marginal olive plants, living in harsh saline conditions could have higher resistance to salt stress. These genotypes, with promising potential genetic value, are on the pathway of regression, or are even endangered plants. Both the selection and characterisation of clones with a superior resistance to limiting conditions and the rescuing of genotypes of high ecological and genetic value could facilitate preservation of the traditional landscape and improve agricultural utilisation.

The presence of $\mathrm{NaCl}$ in the medium changes the mineral composition of olive plants mainly by increasing $\mathrm{Na}$ and $\mathrm{Cl}$ and decreasing $\mathrm{K}$ and $\mathrm{Ca}$ contents (Bartolini et al., 1991). Growth under saline conditions may also affect both anatomical and morphological aspects of leaves in the olive as well as other glycophytic species (Gucci and Tattini, 1997).

Both leaf nutritional content and anatomical characteristics, together with olive plant behaviour, could be linked with the genetic capacity of the plants to adapt to salinity. 
(WC-CO), table 1, and olive plants found growing in harsh saline zones were selected and compared. Three saline zones, each divided into two subzones, were identified for collection of plant material (table 2).

Leaves of the plants of each subzone were sampled to determine nutrient contents and for anatomical observations. For the nutrient composition the plant material was analysed as follows: $\mathrm{N}$ by Kjeldahl digestion; and mineral nutrients $(\mathrm{P}, \mathrm{K}, \mathrm{Ca}, \mathrm{Mg}, \mathrm{Na}$, $\mathrm{Cl}, \mathrm{Fe}, \mathrm{Mn}, \mathrm{Cu}, \mathrm{Zn}$ and $\mathrm{B}$ ) by wet oxidation with concentrated $\mathrm{HNO}_{3}$ under pressure using a Milestone Ethos microwave digestion system. Analysis of mineral nutrients in the extracts was performed by ICP-OES. Soil electric conductivity (EC 1:5) was also measured.

A second series of leaves was fixed in FAE in the field for anatomical studies. Before processing, leaf length and width were measured. Central portions of the leaves were embedded in paraffin, sectioned transversely at $12 \mu \mathrm{m}$, and stained with toluidine blue (Sakai, 1973). Thickness of the leaf, palisade and spongy parenchyma tissues were measured midway between the central vein and leaf border using a Leica Q5001W image analysis system connected to an ocular microscope.

\section{RESULTS AND DISCUSSION}

According to the reports of González et al. (1973), Ferreira et al. (1984), Troncoso (1985), Villalbi and Vidal (1988), the cultivated olive plants from WC-CO showed suitable levels in practically all nutrients (table 1). Only $\mathrm{Cu}$ presented very high levels, probably due to antifungal treatments. As a consequence of their similarity in nutrient composition, it was possible to obtain a representative average nutritional status of the WC-CO olive cultivars (table 2).

The foliar nutrient composition of the plants growing in the harsh saline zones (table 2) presented differences from the above indicated for the WC-CO cultivated plants. In spite of variation among zones, higher $\mathrm{Na}$ and $\mathrm{Cl}$ content was the most notable difference. There was a clear equivalence between the foliar levels of these two elements, indicating that their accumulation was due to presence of $\mathrm{NaCl}$ in soil and air (frequently the plants were wet with saline water from the humid sea air). In consequence, the leaf $\mathrm{Na}$ and $\mathrm{Cl}$ content corresponded with the soil electric conductivity, distance to the sea and possibility of receiving marine winds. Thus plants of C-PR, O-RC and O-AC, with the highest levels of foliar $\mathrm{Na}$ and $\mathrm{Cl}$, had the highest soil electric conductivity $(\varepsilon \mathrm{c}-1: 5$, $\cong$ 2.5-3.5 $\mathrm{dSm}^{-1}$ ), were very close with the sea and exposed to humid marine winds. Plants of $\mathrm{C}-\mathrm{SF}$, with lower contents of $\mathrm{Na}$ and $\mathrm{Cl}$, had the same indicated characteristics, except for being well protected from sea winds. The D-ZA and D-VE subzones with the lowest $\mathrm{Na}$ and $\mathrm{Cl}$ contents were located farther from the sea, their soil electric conductivity was lower $\left(\varepsilon \mathrm{c}-1: 5, \cong 0.6 \mathrm{dSm}^{-1}\right)$ and the plants were protected from marine winds by other high plants species.

Olive trees with high $\mathrm{Na}$ contents presented lower levels of $\mathrm{K}$, showing the well known antagonism between these two elements and indicated by Bartolini et al., (1991) for young olive plants in greenhouse conditions. Olive plants growing in saline zones showed also lower N and Ca contents. Grattan and Grieve (1992) indicated that salinity reduces $\mathrm{N}$ accumulation and Heimler et al. (1995) showed decreased $\mathrm{Ca}$ in the root of olive plants treated with salt. The poor contents of $\mathrm{N}$ and $\mathrm{Ca}$ in the very sandy soil of the chosen salinity zones must also be considered.

Although salinity zone leaves demonstrated high variability, they were generally shorter and thinner, but of similar width to the leaves from WC-CO cvs. Reduced thickness of the saline zone leaves was largely due to reduced spongy parenchyma as compared to the WC-CO cvs. While there was no definitive relationship between $\mathrm{Na}$ and $\mathrm{Cl}$ content and anatomical characteristics, there was a slight tendency, amongst the material from saline zones, for thicker palisade parenchyma, a greater proportion of palisade to spongy parenchyma, and greater total leaf thickness to be associated with higher foliar $\mathrm{Na}$ and $\mathrm{Cl}$. Further studies are required to determine which of the structural characteristics are genetically or physiologically related to the high saline environment, 
and which are simply consequences of the genetic nature of the plant material.

\section{Literature Cited}

Bartolini, G., Mazuelos, C. and Troncoso, A. 1991. Influence of $\mathrm{Na}_{2} \mathrm{SO}_{4}$ and $\mathrm{NaCl}$ salts on survival, growth and mineral composition of young olive plants in inert sand culture. Adv. Hort. Sci. 5:73-76.

Ferreira, J., García Ortíz, A., Frías, L. and Fernández, A. 1984. Los nutrientes N, P, K en la fertilización del olivar. $\mathrm{X}^{\circ}$. Aniv. Red Coop. Europea de Investigación en Oleicultura. Córdoba. 23 p.

González, F., Chávez, M., Mazuelos, C. and Troncoso, A. 1973. Aspectos físiológicos en la nutrición del olivar, variedad "Manzanillo" de mesa. Ciclo de nutrientes en hojas, órganos de crecimiento y producción. Anales de Edafología y Agrobiología. Tomo XXXII, 7-8. 615-634.

Grattan, S.R. and Grieve, C.M. 1992. Mineral element acquisition and growth response of plants grown in saline environments. Agriculture, Ecosystems and Environment, 38, 274-300.

Gucci, R. and Tattini, M. 1997. Salinity tolerance in olive. Hort. Rev. 21: 177-214.

Heimler, D., Tattini, M., Ticci, S., Ckoradechi, M.A. and Traversi, M.L. 1995. Growth, ion accumulation, and lipid composition of two olive genotypes under salinity. J. Plant Nutr. 18(8):1723-1734.

Sakai, W.S. 1973. Simple method for differential staining of paraffin embedded plant material using Toluidine blue O. Stain Technology. 48: 247-249.

Troncoso, A. 1985. Nutrición y fertilización del olivo. Sevilla. Jornadas de aceituna de mesa. Fundación Giménez Fernández y Banco Exterior de España. págs. 118-128.

Villalbi, I. and Vidal, M. 1988. Análisis de sóls i foliars: Interpretació i fertilització. Monografies Obra Agrícola de la Caixa de Pensions. Serie Tecnologia i Economia Agrária, nº, $196 \mathrm{p}$.

\section{Tables}

Table 1. Leaf mineral composition of the selected olive cv.s from Córdoba World Collection (WC-CO).

\begin{tabular}{lccccccc|ccccc}
\hline & \multicolumn{9}{c|}{ \% dm } & \multicolumn{7}{c}{$\mathrm{ppm}$} \\
Olive cv. & $\mathrm{N}$ & $\mathrm{P}$ & $\mathrm{K}$ & $\mathrm{Ca}$ & $\mathrm{Mg}$ & $\mathrm{Na}$ & $\mathrm{Cl}$ & $\mathrm{Fe}$ & $\mathrm{Mn}$ & $\mathrm{Cu}$ & $\mathrm{Zn}$ & $\mathrm{B}$ \\
\hline Galego & 1.93 & 0.11 & 0.86 & 1.42 & 0.20 & 0.02 & 0.02 & 37 & 54 & 74 & 18 & 12 \\
Arbequina & 1.99 & 0.11 & 0.73 & 1.40 & 0.13 & 0.02 & 0.02 & 37 & 41 & 64 & 15 & 13 \\
Picual & 1.93 & 0.14 & 0.73 & 1.99 & 0.15 & 0.02 & 0.02 & 40 & 56 & 67 & 19 & 12 \\
Jabaluna & 1.99 & 0.13 & 0.71 & 1.39 & 0.12 & 0.02 & 0.02 & 39 & 47 & 65 & 20 & 12 \\
C. Jaén & 1.83 & 0.11 & 0.75 & 1.43 & 0.12 & 0.02 & 0.02 & 41 & 50 & 72 & 18 & 13 \\
Cañivano & 1.90 & 0.14 & 0.70 & 1.45 & 0.15 & 0.02 & 0.02 & 39 & 43 & 61 & 20 & 13 \\
Lechín Sevilla & 2.07 & 0.13 & 0.74 & 1.66 & 0.18 & 0.02 & 0.02 & 40 & 45 & 66 & 17 & 11 \\
\hline
\end{tabular}


Table 2. Leaf mineral composition of the selected olive plants.

\begin{tabular}{lccccccc|ccccc}
\hline $\begin{array}{l}\text { Zone-Subzone } \\
\text {-plant N }\end{array}$ & $\mathrm{N}$ & $\mathrm{P}$ & $\mathrm{K}$ & $\mathrm{Ca}$ & $\mathrm{Mg}$ & $\mathrm{Na}$ & $\mathrm{Cl}$ & $\mathrm{Fe}$ & $\mathrm{Mn}$ & $\mathrm{Cu}$ & $\mathrm{Zn}$ & $\mathrm{B}$ \\
\hline WC-CO (Avg.) & 1.95 & 0.12 & 0.75 & 1.53 & 0.15 & 0.02 & 0.02 & 39 & 48 & 67 & 18 & 12 \\
O-RC-1 & 1.34 & 0.10 & 0.61 & 1.33 & 0.17 & 0.34 & 0.35 & 107 & 21 & 23 & 30 & 10 \\
O-RC-2 & 1.42 & 0.10 & 0.64 & 1.48 & 0.22 & 0.49 & 0.50 & 85 & 19 & 22 & 31 & 11 \\
O-RC-3 & 1.42 & 0.11 & 0.60 & 1.38 & 0.18 & 0.30 & 0.27 & 112 & 19 & 28 & 36 & 10 \\
O-AC-1 & 1.46 & 0.13 & 0.67 & 1.06 & 0.14 & 0.30 & 0.33 & 109 & 23 & 19 & 25 & 12 \\
O-AC-2 & 1.63 & 0.12 & 0.66 & 1.28 & 0.16 & 0.28 & 0.29 & 120 & 22 & 28 & 27 & 10 \\
O-AC-3 & 1.65 & 0.12 & 0.68 & 1.21 & 0.15 & 0.18 & 0.20 & 83 & 24 & 22 & 27 & 10 \\
D-ZA-1 & 1.38 & 0.13 & 0.90 & 0.99 & 0.10 & 0.10 & 0.08 & 37 & 14 & 6 & 17 & 13 \\
D-ZA-2 & 1.50 & 0.16 & 0.81 & 0.84 & 0.13 & 0.07 & 0.06 & 45 & 13 & 9 & 19 & 10 \\
D-ZA-3 & 1.24 & 0.17 & 0.75 & 1.06 & 0.10 & 0.05 & 0.05 & 45 & 18 & 5 & 28 & 10 \\
D-VE-1 & 1.28 & 0.10 & 0.70 & 1.06 & 0.13 & 0.04 & 0.03 & 50 & 12 & 8 & 22 & 16 \\
D-VE-2 & 1.49 & 0.10 & 0.83 & 0.81 & 0.10 & 0.02 & 0.03 & 54 & 16 & 5 & 17 & 13 \\
D-VE-3 & 1.39 & 0.06 & 0.80 & 0.88 & 0.10 & 0.03 & 0.03 & 64 & 14 & 5 & 9 & 11 \\
C-SF-1 & 1.29 & 0.14 & 0.67 & 1.16 & 0.17 & 0.15 & 0.16 & 118 & 15 & 10 & 45 & 17 \\
C-SF-2 & 1.62 & 0.16 & 0.80 & 1.16 & 0.17 & 0.16 & 0.16 & 95 & 19 & 18 & 43 & 16 \\
C-PR-1 & 1.72 & 0.12 & 0.53 & 1.39 & 0.24 & 0.70 & 0.60 & 103 & 37 & 10 & 24 & 12 \\
\hline
\end{tabular}

